\title{
TO WHAT EXTENT SHOULD BIOLOGY COURSES BE ADAPTED TO THE PUPIL'S IMMEDIATE ENVIRONMENT?
}

\author{
By Jean Dawson, \\ Normal Training School, Cleveland.
}

A new definition of education has appeared for our consideration. Not that we are surprised, for who of us has not our pet notion of what an education is and where it can best be obtained? We may even confess at being rash enough at times to break out in print with our ideas.

This definition claims our attention, however, first because it does not use schooling and education as synonymous terms as some of us are unconsciously apt to do. And second because it is so broad and comprehensive that no school or higher institution of learning, as they stand today, could or would claim to educate its students. If they could, one hundred institutions of learning would spring up where there is one now, for according to this definition, no one can lay claim to be educated who does not know how to successfully play the game of life.

Imagine what consternation would paralyze our institutions of learning if they were required to teach their students to play this great game suecessfully; what changes in the curriculum would take place; what strife for efficiency of mind and body; what a struggle for the upbuilding of character and the acquirement of a pleasing personality and all the other things that go to make up a successful player in life's great game! What pep and ginger would be infused! But pshaw, what is the use of considering learning the game in our school or college when so many of our so-called educators believe that the training that was given to the ancients is and always will be the proper training for us. Imagine the commercial world taking such a stand! We cannot conceive of an up-to-date merchant holding in stock the goods of the ancients when he knows that there is no demand for them on the part of the modern public. Is it not this very attitude that causes the educational world to lag years behind the world of commerce and causes yearly an army of young men and women to leave college without a working idea of how to make their way in the world?

We would drop this idea of education here, but somehow it challenges further thought. After all, is it Utopian? As a matter of fact doesn't every parent cherish the hope when he sends his child to school that somewhere along the line he may gain a 
requisite knowledge of the game? Is it not this hope that causes any school to be crowded that lays claim to practical work?

Upon further thought we remember that this view of education is not new. No less an authority than the great Huxley, in his Essays on Science and Education, expresses this same idea in classic form.

"Suppose it were perfectly certain that the life and fortune of every one of us would, one day or other, depend on his winning or losing a game at chess. Don't you think that we should all consider it to be a primary duty to learn at least the names and moves of the pieces; to have a notion of a gambit, and a keen eye for all the means of giving and getting out of check? Do you not think that we should look with a disapprobation amounting to scorn upon the father who allowed his son, or the state which allowed its members, to grow up without knowing a pawn from a knight?

"Yet it is a very plain and elementary truth that the life, the fortune, and the happiness of every one of us, and, more or less, of those who are connected with us, do depend upon our knowing something of the rules of a game infinitely more difficult and complicated than chess. It is a game which has been played for untold ages, every man and woman of us being one of the two players in a game of his or her own. The chessboard is the world, the pieces are the phenomena of the universe, the rules of the game are what we call the laws of Nature. The player on the other side is hidden from - us. We know that his play is always fair, just and patient. But we also know, to our cost, that he never overlooks a mistake, or makes the smallest allowance for ignorance. To the man who plays weil, the highest stakes are paid, with that sort of overflowing generosity with which the strong shows delight in strength. And one who plays ill is checkmatedwithout haste, but without remorse."

But let us now come to the consideration of the title of this paper, "To what extent should biology be adapted to the pupil's immediate environment?" With the above definition of education in mind, should we not adapt the course to its fullest extent to the needs of our pupils? Psychologically, must we not go from the near to the remote, from the known to the unknown? I think that it was Coulter who made the statement some years ago that we must educate through, not in, the environment. This is true, but I would go farther and say that only that which is vital to the life of the individual in any particular environment should be taught.

The time and human energy that the average individual cari devote to the subject of biology are so limited that much that is useful and even necessary must be eliminated. We must not use courses in biology that we have taken as a criterion to go by in judging our pupils' needs. Biology with us is vocational. The problem of the teacher in the secondary schools becomes one of selecting that which is rital from that which is merely useful. 
Doubtless you may think that I have in mind the teaching of agriculture. By no means. Agriculture is a vocational subject and the teaching of it should be confined to the vocational and technical schools. The biology that $I$ have in mind is a course that every boy and girl should have regardless of vocation, an underlying stratum of knowledge upon which every life is built; essential rules of the game as it were that must be learned by every successful player.

A case in point is the teaching of enough elementary bacteriology to secure an understanding of sanitation and preventative medicine. The student should gain a clear notion of the nature, growth, reproduction and work of germs and have a knowledge of the causes and the means of prevention of all the contagious diseases. For who can become a successful player if his bodily strength is sapped by the ravages of disease germs? It is safe to say that no one of us would think of teaching the details of such remote diseases as scurvy or sleeping sickness when the student is exposed to a dozen or more diseases of his immediate environment, as diphtheria, typhoid fever and tuberculosis.

A class should have the reports of the latest medical researches and keep in close touch with the practical work in the city. Excursions should be taken to school clinics, tubercular exhibits, sanitaria and baby dispensaries. Lectures and demonstrations should be given before the class by members of the board of health, school physicians and members of the associated charities:

The student will come to realize that careful as he may be, he cannot wholly prevent disease germs from entering his body and that he must rely upon the germicidal power of his blood if he would escape disease. With this end in view, he seeks to take the required amount of fresh air, exercise and baths that lead to physical fitness.

Time does not permit this paper to outline a course in biology vital to the needs of the city. I might go on and cite the study of trees, birds and insects corresponding to the above outline on bacteriology. However it is not necessary. Sufficient to say that we as a people do not know our enemies from our friends. We are doing little or nothing to prevent the loss and even extinction of our best friends, birds, toads and bats, arch enemies of insects that destroy millions upon millions of dollars' worth of produce yearly, to say nothing of the toll they take in unknown thousands of human lives.

Our only hope of controlling such insect ravages is to unite the 
people in a supreme effort to rid themselves of these pests. This can only be done through the proper education. That the average person will act when he learns the truth is illustrated by the effort that the people of Cleveland have made to rid themselves of the filth-disease fly. Until the past spring when the city took charge of the work of eliminating the fly, the movement was carried on by people led by teachers and pupils in the public schools.

To work out a course of vital biology is no mean task. Unfortunately our colleges and universities where we get our training are doing relatively nothing to equip us with a knowledge of practical biology and we find ourselves thrown upon our own resources.

Biology in the normal school has changed from year to year in the course of its adjustment to the people's needs as we have been able to see the light ahead. For instance, two years ago we learned through a series of tests that our entering pupils were amazingly ignorant of the most common plants, vegetables and trees which, hitherto, we had credited them with knowing. Their powers of discrimination were so feeble that they found it diffcult to distinguish a potato from a tomato vine, a willow from a peach leaf, an ash from a hickory, wheat from oats, peas from beans, a cabbage from a turnip, a rose from a blackberry bush.

Now upon entering the school, our first task is to familiarize the pupil with about one hundred specimens of plants. To obviate the difficulty in the future, each outgoing graduate takes to the grade in which she goes to teach about fifty well pressed specimens put up in boxes and covered with glass, under which the plant is spread upon a bed of cotton. These specimens, with names attached, are to be placed in the school-room and the children are invited to go into vacant lots, gardens and by the road side to find plants like them. By this method it is hoped the busy teacher will be enabled to familiarize her pupils with a large number of specimens which they collect themselves and which will cultivate in them the taste for nature study.

In the few minutes left for this paper, perhaps I can show how phases of the work are adjusted and brought into the course. The new work this fall has to do with yards, back and front. While passing through the hamlets, villages and cities in fourteen states, north, south and west of Ohio, this summer, I was greatly impressed by the careless, indifferent, not to say barren and ugly setting of the majority of American homes. I 
am not referring to the slums. These homes were inhabited by good average American families who pride themselves upon comfortable interiors with good plumbing and the use of dustless mops and vacuum cleaners. Lawns were ever present, but the modern built houses stood unadorned with no setting of leaves, vines and shrubs to furnish shade and to relieve the glitter of new paint; blistering in the scorching sun. Poverty cannot be offered as an excuse for the multitude of barren unhome-like American dwellings, with their all too often rubbish strewn back yards, and weedy, ill-kept, ill-arranged vegetable and flower gardens, for a dozen varieties of seedling trees, native shrubs, used by the best landscape gardeners, and wild grape vines, woodbine and virgin bower might be had for the trouble of going to the nearest woodlot.

A new civic conscience is needed and may civic improvement clubs spring up everywhere and send a wave of enthusiasm over the land from coast to coast, from Canada to Mexico. The most effective work, however, can be done in the school.

Unfortunately this lack of well planted, well kept yards is not only true of the fourteen states aforementioned, but it is true of our own state and our own city as well. If any of you want to learn just how' true it is, do as we have been doing. Go out with your kodak in hand, prepared to take pictures of well planted yards.

One hundred and fifteen young women have been at work on the problem this fall. Each is to describe ten yards that she considers well planted and ten that are in dire need of clothing their ugly walls, fences and sheds with the leaves and branches of trees, shrubs and vines and of rounding out straight lines that nature so abhors. The problem centers about the homes of the masses; the planting about wealthy homes is excluded from this list unless it can be copied with little or no expense.

The girls are enthusiastic; fully one thousand homes have been described and about five hundred pictures taken. One girl pointed out to the class the lack of excuse for so much unadorned ugliness in Cleveland when thousands of trees are given away here yearly, sweet honeysuckle vines sell at the five and ten cent store for ten cents apiece, and rambler rose bushes three for a quarter.

Later in the course these girls will receive instruction on the care of the soil and will be given the simple rules of correct planting. Diagrams of their home grounds with its present 
planting will be made, and they will study how they may best be improved. Arrangements have already been made to have the park department give these girls instruction in the propagation of plants, and they will slip, bud and graft under expert direction.

Thus it is hoped that the day will come when cuttings from a favorite shrub or vine may pass from teacher to pupil or from pupil to pupil until even the humblest home in the city may be a picture framed appropriately in trees, vines and shrubs.

\section{RIGIDITY OF THE EARTH.}

An experiment to test the rigidity of the earth has been designed by Professor A. A. Michelson, of the University of Chicago, at the instigation of Professor T. C. Chamberlin, of the Department of Geology, and Professor F. R. Moulton, of the Department of Astronomy. The method consisted, briefly, in measuring with microscopes the changes in level at the ends of a column of water 500 feet long, which half Slled a pipe 6 inches in diameter placed 6 feet under ground to insure constancy of temperature. The attraction of the sun and moon was found to cause tides in the pipe, which were measured every hour, day and night, for two months under the direction of Professor Henry G. Gale. The maximum. changes in level in the 6 -inch pipe amounted at each end to about 0.001 inch. Under Professor Motulton's direction these water tides were 'computed and it was found that they amounted to about seven-tenths only of what they would have been if the earth were absolutely rigid.

To the unscientific mind these facts and figures may seem at first to have but little interest. But when explained the result is little short of startling, since they show that the interior of the earth is not a molten viscous mass, as has been popularly believed, but resists the tidal forces of the moon and sun about as it would if the earth were made of solid steel. Nevertheless the earth in spite of this high rigidity behaves as an elastic body, not liquid, of course, but still subject to the same infiuences (producing tides) as are the oceans which form part of it.

That the solid surface of the earth is subject to the same ebb and flow as are the tides of the ocean, although to a lesser extent, is a statement that will astonish the average person who is prepared to assert with all the assurance of conviction that the earth is a rigid, immovable body. Nevertheless, the fact that there are tides of about a foot in the surface of the earth has been demonstrated as a scientific fact. This is no more remarkable than is the fact that the earth on which we live is a revolving body, yet because it is a new idea and one only recently established, it is likely to strike the unscientific mind as one of the peculiarities of science.

The scientific presentation of the experiment and its results from an astronomical and geological point of view are given in the March issues of the Astrophysical Journal and the Journal of Geology, published by the University of Chicago Press. 